\title{
E cigarettes: Tar Wars: The (Tobacco) Empire Strikes Back
}

\author{
Andy Bush 이 , ${ }^{1}$ Jayesh Bhatt (10), ${ }^{2}$ Jonathan Grigg ${ }^{3}$
}

Students of mythology will recollect that the second Labour of Hercules was to fight Lernaean Hydra, a nine-headed monster with the endearing habit of growing two ferocious heads to replace each one that was cut-off. Autres tempsconventional cigarettes may be on the way out as legislators (although some rather reluctantly) have tightened the noose, with a rich yield of health benefits for children, ${ }^{12}$ but the new Hydra-head of vaping and other means of inhaling nicotine have come on the scene. Far from being given the Hercules treatment (a burning firebrand on the neck stump of the severed head), they have been enthusiastically embraced by Public Health England, ${ }^{3}$ Members of Parliament and others as 'at least 95\% safer than cigarettes', ${ }^{4}$ and proposals to allow vaping in public places are being advanced. By contrast, the European Respiratory Society ${ }^{5}$ and the Federation of International Respiratory Societies $^{6}$ among others ${ }^{7}$ have come out strongly against their use. How should those who care for the respiratory health of children react? Are e-cigarettes the health benefit that their protagonists suggest, or an emerging and sinister threat to lung health?

The first question is, how safe really are e-cigarettes? That they do not produce tar and carbon monoxide is both indisputable and unequivocally better than cigarette smoke. Equally indisputable is that they contain nicotine, which is a drug of addiction and which, in animal models, is highly damaging to the developing fetal lung ${ }^{8-11}$ and brain. ${ }^{12}$ It is also a fact that there are literally thousands of different combinations of compounds and flavourings that can be vaped. These fluids are currently lightly regulated. In one study, all 122 vaping refill liquids studied contained substances having some level

\footnotetext{
${ }^{1}$ Paediatric Respiratory Medicine, Royal Brompton and Harefield NHS Foundation Trust, London, UK

${ }^{2}$ Respiratory Paediatrics, Nottingham Children's Hospital, Nottingham, UK

${ }^{3}$ Academic Division of Paediatrics, Centre for Child Health, Blizard Institute, Queen Mary University of London, London, UK
}

Correspondence to Professor Andy Bush, Department of Paediatric Respiratory Medicine, Royal Brompton Hospital, Sydney, London SW3 6NP, UK; a.bush@imperial.ac.uk of hazard/risk of danger according to the globally harmonised classification system for respiratory irritants. ${ }^{13}$ Even if an investigator could be sure that one fluid was blameless, that certainty could not rationally be extended to any others. Severe acute adverse lung health outcomes in young people (hypersensitivity pneumonitis, ${ }^{14} 15$ diffuse alveolar haemorrhage ${ }^{16}$ ) due to vaping are being increasingly recognised. Collectively, these data show clear breeches of the European Tobacco Products Directive which prohibits the addition of compounds which pose a risk to human health, either when heated or not (only nicotine is excepted) ${ }^{17}$; and we expect that tobacco companies entering the e-cigarette market will use their lobbying skills to undermine strengthened legislation. We should also remember the devastating effects of inadvertent inhalation of one specific humidifier disinfectant in causing interstitial lung disease in Korea $^{18}$ as a corrective to complacency about the inhalation of chemical agents.

We know that, in vitro, vaping fluids have undesirable effects on airway cells, including increasing bacterial adherence ${ }^{19}$ and having proinflammatory effects. ${ }^{20}$ They were equally destructive as tobacco in terms of production of emphysema in a murine model. ${ }^{21}$ We also know that vape fluids have different effects to those of tobacco smoke on bronchial epithelial proteomics, ${ }^{22}$ and this paper strongly suggests that chronic obstructive pulmonary disease (COPD) awaits vapers in the future. Thus those vape fluids that have been studied (a tiny proportion of those available) are not a watered down version of tobacco-they have their own unique brand of adverse effects. From the perspective of protecting the health of young people, these data alone raise red flags. Furthermore, the tobacco industry has not in the past been noted for transparency; indeed there is a major risk that commercial interests will denigrate models of toxicity using the hackneyed approach that any individual mechanistic study does not model effects in 'real life'. We should all take to heart 'Fool me once, shame on you; fool me twice-shame on me'.

It is also a fact that most of the evil effects of smoking (lung cancer, COPD) take decades to manifest. The protagonists of liberalising regulations on vaping acknowledge that the long-term safety of this addiction is not known. Indeed, we are still discovering the adverse effects of tobacco; a recent paper documented an increased risk of death from COPD in non-smoking adults who as children were exposed to secondhand tobacco smoke. ${ }^{23}$ Furthermore, prevention of smoke exposure in public places reduces the risk of preterm birth. ${ }^{2}$ We interpret the discovery of these causative associations after many decades of innocent bystanders being exposed to tobacco smoke means that it will be very many years before we can be sure that passive exposure to vaping is safe. Indeed, although the amount of research is limited, the evidence is that secondhand exposure to vaping emissions is not safe, again hardly surprising. ${ }^{2425}$

The next concern is, whether the use of e-cigarettes by young people is a gateway to tobacco smoking? There is no doubt that for many young people, the first contact with nicotine is in e-cigarettes, and that also, many progress to conventional cigarettes, ${ }^{26}$ and that the use of e-cigarettes is strongly associated with progression to tobacco. $^{27}$ But to debate whether or not e-cigarettes are a gateway to smoking is surely to allow oneself to be diverted by the cleverness of the industry into an irrelevant blind alley. Does anyone seriously think it is desirable that young people should be exposed to nicotine, a known drug of addiction? We need to get across the message that nicotine is a dangerous drug of addiction, and that young people must be warned of the adverse consequences, and protected as far as possible therefrom, rather than propagate bland, utterly non-evidence-based statements about 'safety'. The complacency of Public Health England while thousands of children become nicotine addicted through vaping is a most pusillanimous abrogation of responsibility.

It has been argued that e-cigarettes are a valuable aid to smoking cessation. This is not an area of expertise for these authors, so we have to rely on the published literature. The evidence therein is not convincing, ${ }^{28}$ and indeed in a recent pragmatic trial, paying people to stop smoking was the only effective strategy. ${ }^{29}$ A meta-analysis actually revealed that electronic cigarettes were associated with less quitting among smokers! ${ }^{30}$ Nonetheless, if reputable independent investigators conduct a good clinical trial which shows unequivocal benefit of using e-cigarettes to step down to abstinence (compared with cessation techniques that do not expose 
lower airway cells to high concentrations of nicotine and other putative toxins), we would certainly support their use in that context. However, such a study has to our knowledge yet to be done. Furthermore, even supposing these devices facilitated a few adults to give up smoking, such limited benefit would be outweighed by harm were they to prove a gateway to smoking to a generation of teenagers. ${ }^{31}$

Clearly there is a disconnect between the putative use of e-cigarettes in a smoking cessation clinic, and the way they are being marketed. Anyone who doubts this should compare vaping marketing with that of nicotine patches and gum. Our contention is that vaping is being targeted deliberately to young people-why else would so many different flavours be available? Indeed, 'Juuls' (almost uniquely, not marketed by a tobacco company) is sweeping across USA high schools ${ }^{32}$ and now has more than $70 \%$ of the market share. ${ }^{33}$ Looking like a USB drive, multiple flavours available, Juuls have used nicotine salts which better mimic the nicotine surge of tobacco cigarettes, and are presumptively likely therefore to be even more addictive. ${ }^{34}$ Of course the companies who manufacture Juuls are desperately concerned that they should not be used by children, despite which they are being investigated by the Food and Drug Administration for allegedly targeting young people. $^{35}$ Indeed their kits are highly appealing to this age group. ${ }^{36}$ Others are certainly equally concerned, and no doubt are trying to influence our politicians; the role of dishonour includes the Foundation for a Smoke-Free World, which is funded by Philip Morris International to the extent of $\$ 80$ million annually for 12 years. ${ }^{37}$ Similarly, the widespread internet and other depictions of young and glamorous stars vaping, both male and female, are surely hardly meant to discourage young experimenters.

In summary, the position of the e-cigarette lobby is that because it is known that e-cigarettes do not produce two known harmful substances (tar and carbon monoxide), and because no safety issues have been discovered, e-cigarettes are safer than tobacco. On the contrary, we believe we should align with the large international respiratory societies to say that, unless and until e-cigarettes are proved to be safe, they should be marketed and regulated as cigarettes, because they contain hundreds of unknown and unregulated compounds not found in tobacco. Indeed, we know that there are already substantial safety concerns documented (above). It is solely the responsibility of the industry to prove safety. The regulations that apply to tobacco should be applied to e-cigarettes, including those relating to advertising, packaging, taxation and where they can be used. The only justification for their current use is aligned with nicotine patches and gum for smoking cessation. If we persist in the approach of Public Health England with its disregard for protecting the respiratory health of adolescents and young children, we are risking a further epidemic of devastating lung disease for today's children. Non-evidence-based 'consensus' should not be allowed to determine public policy. We call on the Royal College of Paediatrics and Child Health, and the other Royal Colleges, to join the international voices who are deeply concerned about the vaping epidemic, and do all that can be done to counter it.

Correction notice This paper has been amended since it was published Online First. The paper's title has been modified.

Contributors $A B$ wrote the first draft. All authors reviewed and agreed to the final version.

Funding The authors have not declared a specific grant for this research from any funding agency in the public, commercial or not-for-profit sector.

\section{Competing interests None declared.}

\section{Patient consent for publication Not required.}

Provenance and peer review Commissioned; externally peer reviewed.

(C) Author(s) (or their employer(s)) 2019. No commercial re-use. See rights and permissions. Published by BMJ.

\section{Check for updates}

To cite Bush A, Bhatt J, Grigg J. Arch Dis Child 2019;104:1027-1029.

Received 17 October 2018

Revised 8 November 2018

Accepted 8 November 2018

Published Online First 29 November 2018

Arch Dis Child 2019;104:1027-1029.

doi:10.1136/archdischild-2018-315820

\section{ORCID iDs}

Andy Bush http://orcid.org/0000-0001-6756-9822 Jayesh Bhatt http://orcid.org/0000-0003-0083-7460

\section{REFERENCES}

1 Millett C, Lee JT, Laverty AA, et al. Hospital admissions for childhood asthma after smoke-free legislation in England. Pediatrics 2013;131:e49 5-e501.

2 Cox B, Martens E, Nemery B, et al. Impact of a stepwise introduction of smoke-free legislation on the rate of preterm births: analysis of routinely collected birth data. BMJ 2013;346:f441.

3 McNeill A, Brose LS, Calder R, et al. Evisdence review of e-cigarettes and heated tobacco products 2018. A report commissioned by Public Health England. London. Public Health England 2018.

4 Hartmann-Boyce J, Begh R, Aveyard P. Electronic cigarettes for smoking cessation. BMJ 2018;360:j5543.
5 Ferkol TW, Farber HJ, La Grutta S, et al. Electronic cigarette use in youths: a position statement of the Forum of International Respiratory Societies. Eur Respir J 2018:51:1800278.

6 National Academies of Sciences and Engineering and Medicine. Public health consequences of e-cigarettes. Washington, DC: The National Academies Press, 2018

7 Sekhon HS, Jia Y, Raab R, et al. Prenatal nicotine increases pulmonary alpha7 nicotinic receptor expression and alters fetal lung development in monkeys. J Clin Invest 1999;103:637-47.

8 Sekhon HS, Keller JA, Proskocil BJ, et al. Maternal nicotine exposure upregulates collagen gene expression in fetal monkey lung. Association with alpha7 nicotinic acetylcholine receptors. Am J Respir Cell Mol Biol 2002;26:31-4.

9 Wongtrakool C, Wang N, Hyde DM, et al. Prenatal nicotine exposure alters lung function and airway geometry through $\alpha 7$ nicotinic receptors. Am J Respir Cell Mol Biol 2012;46:695-702.

10 Vardavas C, Girvalaki C, Vardavas A, et al. Respiratory irritants in e-cigarette refill liquids across nine European countries: a threat to respiratory health? Eur Respir J 2017:50:1701698.

11 Wongtrakool C, Roser-Page S, Rivera HN, et al. Nicotine alters lung branching morphogenesis through the alpha7 nicotinic acetylcholine receptor. Am J Physiol Lung Cell Mol Physiol 2007;293:L61 1-L618.

12 Roza SJ, Verburg BO, Jaddoe VW, et al. Effects of maternal smoking in pregnancy on prenatal brain development. The Generation R Study. Eur J Neurosci 2007:25:611-7.

13 United Nations Econnomic Commission for Europe. Globally Harmonized System of Classification and Labelling of Chemicals (GHS. New York, United Nations, 2007. http://www.unece.org/trans/danger/ public/ghs/ghs_rev02/02files_e.html.

14 Narang R, Narang D, Narang S, et al. Good, Bad, and Ugly on Vaping. Chest 2015;148:385A

15 Sommerfeld CG, Weiner DJ, Nowalk A, et al. Hypersensitivity pneumonitis and acute respiratory distress syndrome from e-cigarette use. Pediatrics 2018;141:e20163927.

16 Agustin M, Yamamoto M, Cabrera F, et al. Diffuse Alveolar Hemorrhage Induced by Vaping. Case Rep Pulmonol 2018;2018:1-3.

17 Directive 2015/40/EU of the European Parliament and of the Council of 3 April on the approximation of the laws, regulations and administrative provisions of the Member States concerning the manufacture, presentation and sale of tobacco and related products and repealing Directive 2001/37/EC. http://eur-lex. europa.eu/legal-content/cn/TXT/?uri-CELEX\% 3A3201410040.

18 Kim KW, Ahn K, Yang HJ, et al. Humidifier disinfectantassociated children's interstitial lung disease. Am J Respir Crit Care Med 2014;189:48-56.

19 Miyashita L, Suri R, Dearing E, et al. E-cigarette vapour enhances pneumococcal adherence to airway epithelial cells. Eur Respir J 2018;51:1701592.

20 Scott A, Lugg ST, Aldridge K, et al. Pro-inflammatory effects of e-cigarette vapour condensate on human alveolar macrophages. Thorax 2018:thoraxjnl-2018-211663. epub.

21 Reinikovaite V, Rodriguez IE, Karoor V, et al. The effects of electronic cigarette vapour on the lung: direct comparison to tobacco smoke. Eur Respir J 2018;51:1701661.

22 Ghosh A, Coakley RC, Mascenik T, et al. Chronic E-Cigarette Exposure Alters the Human Bronchial Epithelial Proteome. Am J Respir Crit Care Med 2018;198:67-76.

23 Diver WR, Jacobs EJ, Gapstur SM. Secondhand Smoke Exposure in Childhood and Adulthood in Relation to Adult Mortality Among Never Smokers. Am J Prev Med 2018:55:345-52

24 www.pediatrics.org/cgi/doi/10.1542/peds.2015-3222 
25 Schober W, Szendrei K, Matzen W, et al. Use of electronic cigarettes (e-cigarettes) impairs indoor air quality and increases FeNO levels of e-cigarette consumers. Int I Hyg Environ Health 2014;217:628-37.

26 Fulton E, Gokal K, Griffiths S, et al. More than half of adolescent E-Cigarette users had never smoked a cigarette: findings from a study of school children in the UK. Public Health 2018;161:33-5.

27 Conner M, Grogan S, Simms-Ellis R, et al. Do electronic cigarettes increase cigarette smoking in UK adolescents? Evidence from a 12-month prospective studypiistudy. Tob Control 2017:pii: tobaccocontrol-2016-053539. doi: 10.1136/ tobaccocontrol-2016-053539. [Epub ahead of print].

28 Bullen C, Howe C, Laugesen M, et al. Electronic cigarettes for smoking cessation: a randomised controlled trial. Lancet 2013;382:1629-37.

29 Halpern SD, Harhay MO, Saulsgiver K, et al. A Pragmatic Trial of E-Cigarettes, Incentives, and
Drugs for Smoking Cessation. N Eng/ J Med 2018:378:2302-10.

30 Kalkhoran S, Glantz SA. E-cigarettes and smoking cessation in real-world and clinical settings: a systematic review and meta-analysis. Lancet Respir Med 2016:4:116-28.

31 Leone FT, Carlsen KH, Chooljian D, et al. Recommendations for the appropriate structure, communication, and investigation of tobacco harm reduction claims. An official american thoracic society policy statement. Am J Respir Crit Care Med 2018;198:e90-e105.

32 Barrington-Trimis JL, Leventhal AM. Adolescents' use of "Pod Mos" E-cigarettes - urgent concenrs. N Engl J Med 2018. epub.

33 Craver R. Juul expands e-cig market share gap with Reynolds' Vuse. Winston-Salem Journal 2018 https:// www.journalnow.com/business/juulexpands-ecig-market-share-gap-with-reynolds-vuse/article 0bb4d442-fc0f-5c00-8b05-29bbf95dc985.html.
34 Goniewicz ML, Boykan R, Messina CR, et al. High exposure to nicotine among adolescents who use Juul and other vape pod systems ('pods'). Tob Control 2018:tobaccocontrol-2018-054565.

35 Kamerow D. Start-up e-cigarette brand aims to "improve smokers' lives". BMJ 2018:362:k2930.

36 U.S. Food and Drug Administration. Statement from FDA Commissioner Scott Gottlieb, M.D., on new enforcement actions and a Youth Tobacco Prevention Plan to stop youth use of, and access to, JUUL and other e-cigarettes. https://www.fda.gov/newsevents/ newsroom/pressannouncements/ucm605432.htm.

37 World Health Organization. WHO Statement on Philip Morris funded Foundation for a Smoke-Free World. http://www.who.int/mediacentre/news/statements/ 2017/philip-morris-foundation.

38 Gaga M, Welte T, Troosters T, et al. Electronic cigarettes for smoking cessation. Br Med J http:// www.bmi.com/content/360/bmi.j5543/rapidresponses. 